\title{
The Impact of Supply Chain Relationships and Integration on Innovative capabilities and Manufacturing Performance: The Perspective of Rapidly Developing Countries
}

\author{
The purpose of this research is to investigate the relationships between \\ supply chain relationships/integration, innovative capabilities and \\ manufacturing performance. The study adopts Institutional Theory and \\ Resource Based View Theory to assess relationships in 171 organisations \\ drawn from three rapidly developing countries - Brazil, India, China. Data \\ was collected using the International Manufacturing Strategy Survey (IMSS \\ VI) and analysed using Structural Equation Modelling. The study found that \\ supply chain relationships and integration relates positively to both product \\ and process innovative capabilities. The study also found that both product \\ and process innovative capabilities relate positively to manufacturing \\ performance. Furthermore, there was a positive relationship between \\ product innovative capabilities and process innovative capabilities. The \\ findings provide new insights into manufacturers in the three countries and \\ show that the relationships they build with their customers have encouraged \\ them to develop new innovative capabilities. These new capabilities, in turn, \\ have enabled them to reap benefits of improved manufacturing \\ performance.
}

Keywords: Supply chain management, Innovation, Innovative capabilities, Developing countries, Manufacturing performance.

\section{Introduction}

This study investigates developments in supply chain relationships and integration, innovative capabilities and manufacturing performance in three developing countries Brazil, India and China. The need for more research on innovative capabilities and product development in developing countries has been identified in previous studies (Back, Parboteeah, and Nam 2014; Ren, Eisingerich, and Tsai 2015; Søndergaard, Oehmen, and Ahmed-Kristensen 2016). As organisations in rapidly developing 
countries become more global, they will seek to move up the value chain and may come under pressure from their customers to develop new capabilities. While manufacturers in Brazil, India and China have become major producers and exporters, there is no understanding of whether the relationships with customers have encouraged them to develop product and process innovative capabilities. In turn, there is a lack of empirical evidence to confirm if acquisition of such capabilities has translated into improvements in organisational performance. This study addresses this gap in knowledge.

The key research questions addressed by this study are as follows:

(1) Within the context of manufacturers in rapidly developing countries, do supply chain relationships and integration relate with the development of product and process innovative capabilities?

(2) Do product and process innovative capabilities drive manufacturing performance in these rapidly developing countries?

The importance of examining manufacturing performance is driven by the impact that manufacturing performance has on the economic outcomes and cost competitiveness of manufacturers. According to Zhu and Sarkis (2007), economic performance is considered to be a key priority for manufacturers, particularly those in developing countries.

This study collects empirical data from manufacturing organisations in the three indicated countries and uses Structural Equation Modelling (SEM) to analyse the extent to which supply chain relationships impact innovative capabilities and subsequently manufacturing performance. In effect, the study confirms if improving relationships with supply chain partners can ultimately influence manufacturing performance in a positive manner. 
From a theoretical perspective, the study is based on Institutional Theory and Resource Based View (RBV) of an organisation. The study seeks to understand if Institutional Forces, in the form of Normative Forces (i.e. Supply Chain relationships and integration) can enable manufacturers to develop innovative capabilities and if the consequent development of such capabilities can result in improved competitiveness in the form of manufacturing performance (RBV). Institutional Force theory is relevant when considering factors that encourage organisations to adopt certain practices (e.g. capabilities) and RBV is relevant when considering if organisational capabilities can result in competitive or performance advantage. In effect, the adoption of both theories enable an understanding of the development and interplay of relationships and performance within the same context in line with the approach suggested in a study by Sarkis (2012).

The selection of manufacturers from Brazil, India and China is particularly important. These three countries are considered to be fast growing economies with ambitions to be prominent on the global stage. Not only are they three of the four countries In the BRIC nations (Russia being the fourth) recognised as fast growing economies, there is already evidence that organisations in these countries have differentiated themselves from those in other developing countries. A study by Adebanjo et al. (2015) found that organisations in China and India were more likely to adopt a range of business improvement tools and techniques compared to organisations in other developing countries. The findings from this study provide a collective view of whether manufacturers in these three countries are acquiring and exploiting innovative capabilities, irrespective of differences in culture and other national characteristics. 


\section{Theoretical Background and Literature Review}

This study lends from the theoretical perspectives of Institutional Theory and Resource Based View (RBV). Together, both theories relate to the ability or potential for organisations to make changes to their operations or become more competitive as a result of external forces, internal forces or acquisition of knowledge.

\subsection{Institutional theory}

Institutional theory examines how external pressures affect organisations and their practices and consequently enables a rich understanding of organisational behaviour (Meyer and Rowan 1977; Stanger et al. 2013). Institutional theory proposes that three major forces - coercive, mimetic and normative - impact the practices that organisations adopt as well as the environmental alignment of such practices (DiMaggio and Powell 1983; Meyer and Rowan 1977; Scott 1995). Normative forces refer to the pressure placed on organisations to find legitimacy from their supply chain or other commercial partners (Scott, 2008). The pressure from these supply chain partners can lead to organisations adopting new practices. Coercive forces refer to the pressure on organisations to adopt certain practices or behaviours as a result of legislation or other directives from regulatory authorities (e.g. government). Mimetic forces refer to the competitive pressure to measure up to successful competitors by mimicking or copying practices of such competitors (Zhu and Sarkis 2007). However, theorists have also argued that while institutional forces can compel homogeneity in adoption and implementation of organisational practices, the benefits of such adoption are not guaranteed. This may be because the adoption of identical practices does not imply an identical level of implementation, entrenchment and performance (Shi et al. 2012; Yeung, Cheng, and Lai 2006). In an increasingly competitive marketplace where innovation is seen as important to competitive advantage (Chen, Lin, and Chang 2009), 
there is increasing institutional pressure on organisations to develop innovative capabilities. Organisations are increasingly expecting their suppliers to be initiators and important sources of product and process innovation (Azadegan et al. 2008) and supplier innovativeness is increasingly being evaluated by customers (Winter and Lasch 2016). Innovation and innovative capabilities, therefore, can be viewed through the lens of Institutional theory.

\subsection{RBV theory}

The pressure from institutional forces for organisations to be innovative can lead to adoption of innovation-related activities (Da Silveira 2001). However, for these activities to be truly meaningful, they need to lead to tangible benefits for the adopting organisations. RBV theory has been used to examine and explain differences in performance between organisations (Barney and Griffin 1992; Moyano-Fuentes, Sacristán-Díaz, and Garrido-Vega 2016; Wiengarten et al. 2014). RBV theory suggests that organisations have or are able to acquire unique resources or capabilities which can provide them with competitive advantage (Halley and Beaulieu 2009). Therefore RBV considers organisations to be in possession of capabilities and resources, which leveraged distinctively, can confer competitive advantage (Peteraf 1993) and also explain differences in performance. (Barney 1991). Consequently, RBV theory has been well established as an important and relevant theory for examining the relationship between innovative capabilities and organisational performance (Kang and Park 2012; Yeung, Lai, and Yee 2007).

Innovativeness has been recognised as an important organisational capability that can lead to competitive advantage (Cheng, Chen, and Huang 2014; Golgeci and Ponomarov 2013). Chen, Lin and Chang (2009) similarly stressed that the ability to 
innovate can lead to the competitive advantage alluded to by Barney (1991). Therefore $\mathrm{RBV}$ is a suitable theory to examine the relationship between innovativeness and performance. However, it has been suggested that innovation and innovative capabilities of organisations in developing countries may differ from those of developed countries (Pietrobelli and Rabellotti 2011) and, therefore, it is important to study developing countries in their own right. Therefore the context of this study helps to understand the extent to which manufacturers in developing countries are developing and exploiting innovative capabilities.

\subsection{Literature review}

\subsubsection{Supply Chain Relationships and Integration}

The management of supply chains, particularly within the context of outsourcing, implies the need and ability to manage relationships within the supply chain network (Chen and Fung 2013). Within the supply chain literature, a great deal of emphasis has been placed on supplier relationships and integration. According to Tsai and Hung (2016) and Lee, Kwon, and Severance (2007), supply chain performance can be improved by developing a well-integrated supply chain and the greater emphasis on supplier relationships and integration could be as a result of the important input role that suppliers play in a manufacturing operation (Hornibrook, Fearne, and Lazzarin 2009; Huang, Yen, and Liu 2014). However, relating and integrating with customers is also an important dimension of supply chain management as it impacts demand management, order management, product information and delivery (Lee, Kwon, and Severance 2007). Integration of processes with customers has been credited with the ability to improve relationships and boost co-dependency (Day 2000). Studies such as Souitaris (2001) have further suggested that organisations that improve their relationships with 
customers could develop an innovation advantage while others (e.g. Appiah-Adu and Singh 1998; Shum and Lin 2007) have found a positive link between customer orientation and organisational innovation. However, despite increasing evidence that manufacturers are under increasing pressure by their customers to adopt innovative practices and improve their innovative capabilities (Laosirihongthong, Punnakitikashem, and Adebanjo 2013), the relationship between customer relationship and integration and the development of innovative capabilities of manufacturers remains largely unexplored. The authors would also argue that there is even less understanding of this relationship in developing countries such as China, India and Brazil where manufacturers have primarily been long perceived as low-cost contract manufacturers rather than repositories of innovative capabilities.

\subsubsection{Innovative Capabilities}

Innovation is defined by Morton and Burns (2008) as 'the process of bringing new and improved products and processes to market; developing, adopting and adapting manufacturing processes to enhance productivity and product quality; and developing, adopting and adapting business practices to enhance the performance of the firm'. Leskovar-Spacapan and Bastic (2007) argued that understanding innovation encompasses innovativeness in product development, process technologies and management practices. The distinction between product and process innovation has also been highlighted by authors such as Bullinger, Auernhammer, and Gomeringer (2004) and Laosirihongthong, Prajogo, and Adebanjo (2014). From a RBV perspective, the ability on an organisation to develop innovative capabilities should lead to competitive benefits for the organisation. According to Wagner et al. (2011), the ultimate aim of all innovation-based activities is to improve organisational efficiency and maintain market competitiveness. 
There are still uncertainties about the ability of organisations in developing countries to acquire the level of innovative capabilities that their counterparts in more developed countries have. This may be because innovation systems are different when these two classifications of countries are compared (Pietrobelli and Rabellotti 2011). It has also been suggested that innovation systems in developing countries are poorly developed, poorly structured and starved of resources, access to technology, access to knowledge and possess insufficient human capital (Berger and Diez 2008). Furthermore, organisations in developing countries may be reluctant to invest in innovation because such investment is expensive and very risky (Back, Parboteeah, and Nam 2014). The underlying reasons for the perceived lag in developing countries may be due to the more recent arrival of organisations in such countries to the global manufacturing stage and their initial focus on contract manufacturing. In addition organisations in developing countries may typically have fewer resources to direct to the development of innovative capabilities. Therefore, if the development of innovative capabilities in developing countries suffers from a number of fundamental issues, a pertinent question to ask however, is if the increasing involvement of organisations in developing countries with supply chain partners has influenced the development of such capabilities.

\subsubsection{Manufacturing Performance}

It has already been argued that one of the goals of improving innovative capabilities in an organisation is to improve organisational performance. Within the context of manufacturing organisations, manufacturing performance has been measured in different ways. For example studies such as Eltayeb, Zailani, and Ramayah (2011) and Zhu and Sarkis (2004) which were focused on sustainability issues considered manufacturing performance by considering measures such as waste reduction, energy reduction and improved productivity. Other studies such as Fullerton, Kennedy, and 
Widener (2014) evaluated lean operations in manufacturers by using operational measures such as reduction in scrap and rework, machine downtime, cycle time and lot sizes. With particular respect to innovativeness, Lin (2004) argued that manufacturing flexibility is an important dimension of performance and consequently, this study adopts measures that relate to manufacturing flexibility. However, it has also been argued that organisations that improve product and process innovativeness are likely to suffer more product failure costs and less product reliability (Mackelprang, Habermann, and Swink 2015). Therefore, this study also adopts measures that relate to quality and reliability which are important measures of manufacturing performance when product and/or process innovation are concerned.

\section{Hypotheses Development}

\subsection{Supply chain relationships, integration and innovation.}

Ren, Eisingerich, and Tsai (2015) suggested that most organisations in developing countries such as China are technology followers rather than leaders and are subject to control by western customers. Bellamy, Ghosh, and Hora (2014) suggested supply chain partners can leverage normative forces to drive their suppliers to develop innovative capabilities. The potential effect of leveraging normative forces is that manufacturers tend to tailor their innovation-related activities to customer needs (Bullinger, Auernhammer, and Gomeringer 2004). Customer needs often involve the ability to develop product innovative capabilities (Mishra, Chandrasekaran, and MacCormack 2015). The leveraging of normative forces between customers and suppliers is driven in different ways including the forging of closer relationships and integration of systems (Laosirihongthong, Prajogo, and Adebanjo 2014). Therefore, institutional forces could 
be important to the willingness of suppliers to develop innovative capabilities.

Consequently, it is proposed that:

H1. Improvement in supply chain relationship and integration will relate positively with improvement in product innovative capabilities in manufacturing organisations in developing countries.

However, innovative capabilities do not only apply to products but also to processes. The distinction between process and product is well recognised in literature (Leskovar-Spacapan and Bastic 2007; Morton and Burns 2008). Therefore, while there might be a tendency to focus on developing innovative products in order to capture the consumer's attention, it is important not to relegate process innovation particularly as authors such as Lu and Botha (2006) have suggested that there is relatively less focus on process innovation. However, as previously argued, manufacturers in developing countries operate in an environment where investment in innovative capabilities is difficult and where the primary focus was on contract manufacturing and not innovation. It is therefore important to understand if improved relationships and integration with customers will have an impact on process innovativeness in developing countries. Consequently, the following is hypothesised:

H2. Improvement in supply chain relationship and integration will relate positively with improvement in process innovative capabilities in manufacturing organisations in developing countries.

\subsection{Product and process innovative capabilities}

Many scholars consider innovation to consist of, at least, two dimensions - product innovation and process innovation (e.g. Bullinger, Auernhammer, and Gomeringer 2004; Laosirihongthong, Prajogo, and Adebanjo 2014). From a customer and marketing perspective, the allure of product innovation and new product development is 
easy to understand. Product innovation has the potential to excite customers and deliver new streams of income (Kleinschmidt and Cooper 1991; Teece 2010). However, Martínez-Ros and Labeaga (2009) and Ballot et al. (2015) stressed that product and process innovation have a complementary relationship and could lead to each other. Linton (2015) went further to suggest that product innovation tends to lead process innovation when assembled products are considered. Based on these studies and the finding that all types of innovation are dependent on possessing the right capabilities (Tavassoli and Karlsson 2015), it is important to investigate the relationship between product and process innovative capabilities. Hence, it is hypothesised as follows:

H3a. Improvement in product innovative capabilities will relate positively with improvement in process innovative capabilities in manufacturing organisations in developing countries.

H3b. Improvement in product innovative capabilities will partially mediate the relationship between supply chain relationship and integration and Improvement in process innovative capabilities.

\subsection{Innovative capabilities and manufacturing process performance}

The key driver of product innovative capabilities is the need to be competitive (Leskovar-Spacapan and Bastic 2007). From a RBV perspective, product innovativeness and its potential to lead to novelty should lead to competitive advantage. Such competitiveness should not, however, only involve the marketing potential of new or novel products but also needs to consider other factors of performance. This link between product innovativeness and performance has been considered in many studies (e.g. Chudnovsky, Lopez, and Pupato 2006; Crespi and Zuniga 2012; Griffith et al. 2006). Similarly, Yang et al. (2015) found that innovation capability has a significant impact on supply chain performance. Furthermore Chudnovsky, Lopez, and Pupato 
(2006) stressed that while the link between innovativeness and performance is well established for developed countries, there is much less certainty about the link in developing countries.

H4. Improvement in product innovative capabilities will relate positively with improvement in manufacturing performance in developing countries.

The previous distinction that has been made between process and product innovative capabilities makes it imperative to also consider the impact of process innovative capabilities on manufacturing performance. The potential positive impact of process innovation on manufacturing performance has also been discussed in previous studies (e.g. Chudnovsky, Lopez, and Pupato 2006; Oke and Kach 2012) to include improvements in the production process, efficiency and cost. Therefore, from a RBV perspective, the development of process innovative capabilities could lead to improvements in manufacturing performance. Consequently, the following is hypothesised:

H5. Improvement in process innovative capabilities will relate positively with improvement in manufacturing performance in developing countries.

\section{Methodology}

\subsection{Measures and data collection}

A review of operation research literature provided a set of measures that were modified to fit the context of this study. To ensure content validity, the survey items were refined by several academic experts from over 20 countries before being finalised. The survey instrument is presented in Appendix. The five measurement items of supply chain relationship and integration were adapted from Bradley (2005), Ellinger, Daugherty, and Keller (2000), Frohlich and Westbrook (2001), Giménez and Ventura (2005), 
Gunasekaran, Patel, and Tirtiroglu (2001) and Spekman (1988). Product innovative capabilities was assessed using four measurement items adapted from Boer, Kuhn, and Gertsen (2006) and Paashuis and Boer (1997). The scale of process innovative capabilities was assessed using three items introduced in this study. These three scales were assessed for effort in the current level of implementation using a five-point Likert scale where 1 represents none and 5 represents high. A six-item scale adapted from Ahmed (1996), Forza and Filippini (1998), Garvin (1987), Hult, Hurley, and Knight (2004), Jack and Raturi (2002), Ferdows and De Meyer (1990), Kim and Arnold (1993), Kimura, Matoba, and Mitsui (2007), Hallgren and Olhager (2009), and Sitkin, Sutcliffe, and Schroeder (1994), was used to measure the current performance compared with that of main competitor. For this study, we have examined manufacturing performance using a combination of quality and flexibility as opposed to indices already widely explored in the literature (e.g. cost). This is because quality and flexibility should be major concerns in both product and process innovativeness thinking. A case for examining the relationship between innovativeness and manufacturing flexibility was made by Lin (2004). Manufacturing flexibility has also been identified as an important issue within the context of production management (Mendes and Machado, 2015). All responses for manufacturing performance (i.e., the indicator of current performance compared to main competitor) were assessed using a five-point Likert scale where 1 represents much lower, 2 represents lower, 3 represents equal, 4 represents higher, and 5 represents much higher.

The research model (see Figure 1) was tested using data collected through the International Manufacturing Strategy Survey (IMSS) version VI. IMSS version VI was a large scale global project, carried out between June 2013 and June 2014, with the participation of researchers across 23 countries. The sample frame used by each country 
was restricted to employees whose job titles included plant, production, operation managers or chief operating officers of manufacturing firms. IMSS version VI primarily focused on respondents from manufacturing firms indexed in the International Standard Industrial Classification (ISIC) codes ranging from 25, 26, 27, 28, 29 to 30. Several manufacturing firms were contacted to participate in the survey. Subsequent to consent for research participation, survey questionnaires were distributed to the firms. Given that it was a global study, data were compiled in a standardised electronic spreadsheet by all country coordinators. At the end of the data collection, the project leader conducted thorough validity and quality checks, and shared the final pooled dataset with the country coordinators.

\section{(Insert Figure 1 here)}

All country samples were checked for early- and late-response bias and nonresponse bias before being compiled in the IMSS database. For early- and late- response bias test, each country coordinator was required to compare the responses from the earlyrespondents and late-respondents (Armstrong and Overton 1977). A $t$-test of difference was carried out for sales figures, number of employees and SIC code for early- and laterespondents. For non-response bias test, each country coordinator compared the responses of respondents who returned the survey to those who did not answer the survey. A $t$-test of difference was performed for sales figures, number of employees and SIC code for respondents and non-respondents by each country coordinator. A Chi-square test of difference was tested for SIC code of respondents and non-respondents. No statistical difference was found between the responses of respondents and non-respondents.

For the purpose of this study, a total of 171 survey responses were used to test the research hypotheses. The dataset included 28 (16.4\%) responses from Brazil, 56 (32.7\%) from India and 87 (50.9\%) from China. In terms of the registered ISIC code, 24 (14.0\%) 
had ISIC 25, 47 (27.5\%) had ISIC 26, $31(18.1 \%)$ had ISIC 27, $26(15.2 \%)$ had ISIC 28, $32(18.7 \%)$ had ISIC 29, and remaining $11(6.4 \%)$ had ISIC 30. All respondents were executives whose job titles included chief executive officers (CEO), directors, general managers, operations manager and plant managers. Table 1 show the demographic profiles of the respondents.

The study used the maximum-likelihood (ML) approach in the AMOS program to test the hypothesised model. Using the structural question modelling (SEM), the study assessed the model fit using eight common measures including normed chi square $\left(\chi^{2}\right)$, goodness-of-fit (GFI) index, adjusted goodness-of-fit (AGFI) index, root mean square error of approximation (RMSEA), root mean square residual (RMR), normed fit index (NFI), Tucker Lewis index (TLI), and comparative fit index (CFI). All paths were examined by allowing the relationships to be estimated freely in the model.

(Insert Table 1 here)

\subsection{Factor analysis, reliability and validity}

The study performed a principal-component exploratory factor analysis for each survey item to check for the specified constructs. Table 2 shows the results of factor analysis. All the items of each construct had high factor loadings between 0.725 and 0.896 , exceeding the recommended coefficient of 0.50 (Hair et al. 2010). The study also examined the internal consistency reliabilities of the constructs. As presented in Table 3, every construct had Cronbach's Alpha ranging from 0.840 to 0.900 , meeting the desirable value of 0.70 (Hair et al. 2010). The study also checked the composite reliability of all constructs. Referring to Table 3, the values of composite reliability, ranging from 0.894 to 0.928 , were above the recommended value of 0.60 (Bagozzi and Yi 1988). The values of average variance extracted (AVE) for each construct were above 0.50 , indicating convergent validity. In addition, discriminant validity was 
supported as the values of square roots of AVE were greater than the off-diagonal measures in the correlation table (Fornell and Larcker, 1981) (see Table 4). To address the problem of multicollinearity, the study evaluated multicollinearity through the variance inflation factors (VIF). As presented in Table 3, the values of all variables were between 1.287 and 1.942, lower than the recommended thresholds of 3 (Hair et al. 2010), thereby confirming there was no multicollinearity problem in this study.

(Insert Table 2 here)

(Insert Table 3 here)

(Insert Table 4 here) 
The SEM results showed a good model fit with normed chi square $\left(\chi^{2}\right)=1.114$, $\mathrm{GFI}=0.923, \mathrm{AGFI}=0.893, \mathrm{RMSEA}=0.026, \mathrm{RMR}=0.053, \mathrm{NFI}=0.928, \mathrm{TLI}=0.990$, and $\mathrm{CFI}=0.992$. As shown in Tables 5, supply chain relationship and integration has a significant and positive relationship with product innovative capabilities $(\beta=0.682 ; p$ value $<0.001)$. Supply chain relationship and integration was positively related to process innovative capabilities $(\beta=0.294 ; p$-value $<0.01)$. There is a positive relationship between product innovative capabilities and process innovative capabilities $(\beta=0.475 ; p$-value < 0.001). Product innovative capabilities was positively related to supply chain relationship and integration $(\beta=0.270 ; p$-value $<0.05)$. Process innovative capabilities $(\beta=0.305 ; p$ value $<0.05$ ) was found to have a significant and positive relationship with manufacturing performance. The results provided evidence to support H1, H2, H3a, H4 and H5.

\section{(Insert Table 5 here)}

The significant positive relationship between product innovative capabilities and process innovative capabilities resulted in the testing of a mediating effect for product innovative capabilities. The bootstrap approach (Preacher and Hayes, 2004) was adopted to test the mediation hypotheses. The indirect effect of product innovative capabilities on process innovative capabilities was calculated as the product of the path coefficients between supply chain relationships and integration and product innovative capabilities $(\beta=0.682)$ and between product innovative capabilities and process innovative capabilities $(\beta=$ 0.475). This indirect effect coefficient was equal to 0.324 , which can be validated for significance using a bootstrap approach. The results of bootstrapped tests are tabulated in Table 5. The indirect effects were significant given that the lower confidence interval of the bias-corrected bootstrap does not contain zero. As both direct and indirect effects were significant, the partial mediating effect $(\mathrm{H} 3 \mathrm{~b})$ was supported for product innovative capabilities. 
(Insert Table 6 here)

\section{Discussion}

This study set out to investigate the impact of supply chain relationships and integration on innovative capabilities and, subsequently, manufacturing performance. Some studies had suggested that developed countries are not as likely to be advanced in terms of the relationships between supply chain relationship and integration, product innovative capabilities, process innovative capabilities and manufacturing performance (Back, Parboteeah, and Nam 2014; Ren, Eisingerich, and Tsai 2015). However, the findings from this study have shown that this is not necessarily the case and, in fact, manufacturers in developing countries have strong performance in regards to these relationships.

\subsection{The relationships between supply chain relationship/integration and innovative capabilities}

The study shows that for manufacturers in developing countries, supply chain relationship and integration have a significant positive relationship with product innovative and process innovative capabilities. Therefore the suggestion of Bellamy, Ghosh, and Hora (2014) that the supply chain and, particularly, customers can be a driver of innovation is supported by the findings of this study. The strong relationship between supply chain relationship and integration and innovative capabilities in developing countries suggests that both the manufacturers and their customers have understood a focus on how their relationship may be used to develop the innovative capabilities. Consequently, the study confirms the established effects of institutional forces in developing countries within the context of driving the acquisition of product and process innovative capabilities. Therefore, these findings from this study suggest 
that that manufacturers in developing countries have responded positively to the demands of supply chain relationships and integration.

According to Back, Parboteeah, and Nam (2014), developing innovative capabilities is a costly venture fraught with risk, and therefore, unattractive to manufacturers in developing countries. The findings from this study suggest otherwise. They suggest an openness to developing both product and process innovative capabilities. To a certain extent, the challenges of affordability would have been addressed by the investment of national governments in promoting innovation as well as the increasing willingness of western manufacturers to set up R \& D facilities in developing countries (Cho et al. 2009; Rao, Chandra, and Shin 2012; Xu and Chi 2009). In conclusion the study finds that an increase in integration between suppliers and customers could lead to improvements in innovativeness (Seo, Dinwoodie, and Kwak 2014).

From a theoretical perspective, the findings imply that Institutional pressures such as pressure from supply chain customers can lead to the development of product and process innovative capabilities. In effect, findings from this study suggest Institutional forces in the form of supply chain relationship and integration forces can lead to the development of innovativeness competencies in manufacturers.

From a competitive perspective, the findings from this study suggest that manufacturers in developing countries are focusing increasingly on product and process innovative capabilities. If and when they develop such capabilities to an advanced level, the impact on global manufacturing and trading relationships could become very significant. 


\subsection{The relationship between product and process innovative capabilities}

Previous studies including Linton (2015) and Martínez-Ros and Labeaga (2009) have found relationships between product innovation and process innovation. Linton (2015), in particular suggested that product innovation drives process innovation for assembled goods. This study, while examining innovative capabilities, found that for manufacturers in developing countries, product innovative capabilities have a strong positive relationship with on process innovative capabilities. This is an important finding as it suggests that having strong product innovative capabilities can influence the development of process innovative capabilities. The implication, therefore is that if manufacturers in developing countries expend time and effort on the competencies that drive product innovation, they are then also likely to focus on competencies that drive process innovation.

\subsection{The relationships between innovative capabilities and manufacturing performance}

The study found that both product and process innovative capabilities have significant positive relationships with manufacturing performance. While the relationships are not as strong as those between innovativeness and supply chain relationships/integration, they are never-the-less positive relationships that indicate that developing product and process innovativeness can positively influence manufacturing performance as indicated by manufacturing flexibility and process quality.

From a theoretical perspective, manufacturers in developing countries have exploited the RBV potential of product and process innovative capabilities to improve their competitiveness in terms of manufacturing flexibility and quality. 


\subsection{The mediating effects of product innovative capabilities}

The results of the mediating test provides evidence that developing of product innovative capabilities can partially mediate between supply chain relationships/integration and process innovative capabilities. Therefore developing product innovative capabilities in manufacturers in developing countries can be pivotal to both acquiring process innovative capabilities and achieving positive manufacturing performance.

From a theoretical perspective, the institutional forces related to supply chain relationship and integration drive RBV competencies of product and process innovative capabilities and the RBV competencies of product and process innovativeness associate positively with manufacturing performance.

\section{Conclusions and Limitations}

The study set out to investigate if supply chain relationship and integration drive the development of process and product innovative capabilities and if these, in turn, have an effect of manufacturing performance. The study found that supply chain relationship and integration relates positively to the development of both dimensions of innovative capabilities and that innovative capabilities relate positively to manufacturing performance.

These findings have significant implications for industry and academia. For industry, manufacturers in developing countries need to better understand customer requirements for innovativeness and deploy suitable resources to develop their product and process innovative capabilities. This is because both product and process capabilities will ultimately affect competitive performance. Manufacturers would need to deploy resources to enable development of such capabilities but this should be considered an investment that will bear positive results in the form of manufacturing 
performance. The significant influence of the customers also implies that manufacturers in developing countries need to look beyond being contract manufacturers and work closely with their customers to ensure that their innovative capabilities are aligned with market requirements. Finally, it is important to understand that a desire to develop product innovative capabilities can also be exploited to spur the development of process innovative capabilities as there is a positive relationship between both capabilities. For academia, the findings suggest the need to understand how different forces faced by manufacturers in developing countries can affect their organisational performance and competitiveness. In particular, other forces not considered in this study (e.g. mimetic forces) and the impact they can have in the new competitive environments of developing countries come to the fore. In addition, there is a need for further studies on manufacturers in developing countries to understand how their relationships with supply chain partners are increasingly influencing the way they operate and the skills that they acquire.

Finally, the study's limitations are presented. Firstly, this study only considered three countries - Brazil, India and China. These countries are generally considered to be advancing faster than other developing countries and therefore, the findings may not be necessarily apply to other developing countries. Secondly, differences in national cultures or other national indicators were not taken into account in this study. Future studies could consider if national cultures have a noticeable impact on the relationships examined in this study. Thirdly, the study has used a specific set of measures in its assessment of the four constructs used and there are several other measures that have been used in different studies. 


\section{References}

Adebanjo, D., M. Tickle, T. Laosirihongthong, and R. Mann. 2015. "A Study of the Use of Business Improvement Initiatives: The Association with Company Size and Level of National Development.” Production Planning \& Control 26 (7): 507524. doi: http://dx.doi.org/10.1080/09537287.2014.927931.

Ahmed, J. 1996. "Modern Approaches to Product Reliability Improvement." International Journal of Quality and Reliability Management 13 (3): 27-41. doi: http://dx.doi.org/10.1108/02656719610116063.

Appiah-Adu, K., and S. Singh. 1998. "Customer Orientation and Performance: A Study of SMEs." Management Decision 36 (6): 385-394. doi: http://dx.doi.org/10.1108/00251749810223592.

Armstrong, J., and T. Overton. 1977. "Estimating Nonresponse Bias in Mail Surveys." Journal of Marketing Research 14 (3): 396-402. doi: 10.2307/3150783.

Azadegan, A., K. Dooley, P. Carter, and J. Carter. 2008. "Supplier Innovativeness and the Role of Interorganizational Learning in Enhancing Manufacturer Capabilities." Journal of Supply Chain Management 44 (4): 14-35. doi: 10.1111/j.1745-493X.2008.00070.x.

Back, Y., K. P. Parboteeah, and D. Nam. 2014. "Innovation in Emerging Markets: The Role of Management Consulting Firms." Journal of International Management 20 (4): 390-405. doi: http://doi.org/10.1016/j.intman.2014.07.001.

Bagozzi, R., and Y. Yi. 1988. "On the Evaluation of Structural Equation Models." Academy of Marketing Science $16 \quad$ (1): 74-94. doi: https://doi.org/10.1177/009207038801600107.

Ballot, G., F. Fakhfakh, F. Galia, and A. Salter. 2015. "The Fateful Triangle: Complementarities in Performance between Product, Process and Organizational 
Innovation in France and the UK." Research Policy 44 (1): 217-232. doi: http://doi.org/10.1016/j.respol.2014.07.003.

Barney, J. 1991. "Firm Resources and Sustained Competitive Advantage." Journal of Management 17 (1): 99-120. doi: https://doi.org/10.1177/014920639101700108.

Barney, J. B., and R. W. Griffin. 1992. The Management of Organization: Strategy, Structure, Behaviour. Houghton Mifflin College Div.

Bellamy, M. A., S. Ghosh, and M. Hora. 2014. "The Influence of Supply Network Structure on Firm Innovation.” Journal of Operations Management 32 (6): 357373. doi: http://doi.org/10.1016/j.jom.2014.06.004.

Berger, M., and J. R. Diez. 2008. “Can Host Innovation Systems in Late Industrializing Countries Benefit from the Presence of Transnational Corporations? Insights from Thailand's Manufacturing Industry.” European Planning Studies 16 (8): 10471074. doi: http://dx.doi.org/10.1080/09654310802315708.

Boer, H., J. Kuhn, and F. Gertsen. 2006. “Continuous Innovation: Managing Dualities through Co-Ordination." Continuous Innovation Network Working Paper, WP2006-01. Accessed 11 March 2016. http://www.continuousinnovation.net/publications/working-papers/wp2006-01-boer-kuhn-gertsen.pdf

Bradley, F. 2005. International Marketing Strategy. United States: Financial Times/Prentice Hall.

Bullinger, H., K. Auernhammer, and A. Gomeringer. 2004. "Managing Innovation Networks in the Knowledge-Driven Economy." International Journal of Production $\quad$ Research $42 \quad$ (17): 3337-3353. doi: http://dx.doi.org/10.1080/00207540410001695970. 
Chen, I. S., and P. K. Fung. 2013. "Relationship Configurations in the Apparel Supply Chain." Journal of Business \& Industrial Marketing 28 (4): 303-316. doi: http://dx.doi.org/10.1108/08858621311313901.

Chen, Y. S., M. J. Lin, and C. H. Chang. 2009. "The Positive Effects of Relationship Learning and Absorptive Capacity on Innovation Performance and Competitive Advantage in Industrial Markets.” Industrial Marketing Management 38 (2): 152158. doi: http://doi.org/10.1016/j.indmarman.2008.12.003.

Cheng, J. H., M. C. Chen, and C. M. Huang. 2014. “Assessing Inter-Organizational Innovation Performance through Relational Governance and Dynamic Capabilities in Supply Chains.” Supply Chain Management: An International Journal 19 (2): 173-186. doi: http://dx.doi.org/10.1108/SCM-05-2013-0162.

Cho, J., D. Kim, S. W. Kim, and J. Oh. 2009. "Factors Affecting on the Performance of Overseas R\&D.” Asian Journal on Quality 10 (2): 43-56. doi: $10.1108 / 15982680980001444$.

Chudnovsky, D., A. López, and G. Pupato. 2006. "Innovation and Productivity in Developing Countries: A Study of Argentine Manufacturing Firms' Behavior (1992-2001)." Research Policy $35 \quad$ (2): 266-288. doi: http://doi.org/10.1016/j.respol.2005.10.002.

Crespi, G., and P. Zuniga. 2012. "Innovation and Productivity: Evidence from Six Latin American Countries." World Development 40 (2): 273-290. doi: http://doi.org/10.1016/j.worlddev.2011.07.010.

Da Silveira, G. 2001. "Innovation Diffusion: Research Agenda for Developing Economies.” Technovation 21 (12): 767-773. doi: http://doi.org/10.1016/S01664972(01)00007-4. 
Day, G. 2000. "Managing Market Relationships.” Journal of the Academy of Marketing Science 28 (1): 24-30. doi: https://doi.org/10.1177/0092070300281003.

DiMaggio, P. J., and W. W. Powell. 1983. "The Iron Cage Revisited: Institutional Isomorphism and Collective Rationality in Organizational Fields." American Sociological Review 48 (2): 147-160.

Ellinger, A.E., P. J. Daugherty, and S. B. Keller. 2000. "The Relationship between Marketing/Logistics Interdepartmental Integration and Performance in U.S. Manufacturing Firms: An Empirical Study.” Journal of Business Logistics 21 (1): $1-22$.

Eltayeb, T., S. Zailani, and T. Ramayah. 2011. "Green Supply Chain Initiatives among Certified Companies in Malaysia and Environmental Sustainability: Investigating the Outcomes." Resources, Conservation and Recycling 55 (5): 495-506. doi: http://doi.org/10.1016/j.resconrec.2010.09.003.

Ferdows, K., and A. D. Meyer. 1990. "Lasting Improvements in Manufacturing Performance: In Search of a New Theory.” Journal of Operations Management 9 (2): 168-184. doi: https://doi.org/10.1016/0272-6963(90)90094-T.

Fornell, C., and D. F. Larcker. 1981. "Structural Equation Models with Unobservable Variables and Measurement Error: Algebra and Statistics." Journal of Marketing Research 18 (3): 382-388. doi: 10.2307/3150980.

Forza, C., and R. Filippini. 1998. "TQM Impact on Quality Conformance and Customer Satisfaction: A Causal Model.” International Journal of Production Economics 55 (1): 1-20. doi: http://doi.org/10.1016/S0925-5273(98)00007-3.

Frohlich, M.T., and R. Westbrook. 2001. "Arcs of Integration: An International Study of Supply Chain Strategies.” Journal of Operations Management 19 (2): 185-200. doi: http://doi.org/10.1016/S0272-6963(00)00055-3. 
Fullerton, R. R., F. A. Kennedy, and S. K. Widener. 2014. "Lean Manufacturing and Firm Performance: The Incremental Contribution of Lean Management Accounting Practices." Journal of Operations Management 32 (7-8): 414-428. doi: http://doi.org/10.1016/j.jom.2014.09.002.

Garvin, D. A. 1987. "Competing on the Eight Dimensions of Quality." Harvard Business Review 65 (6): 101-109.

Giménez, C., and E. Ventura. 2005. "Logistics-Production, Logistics-Marketing and External Integration: Their Impact on Performance.” International Journal of Operations \& Production Management 25 (1): 20-38. doi: http://dx.doi.org/10.1108/01443570510572222.

Golgeci, I., and S. Y. Ponomarov. 2013. "Does Firm Innovativeness Enable Effective Responses to Supply Chain Disruptions? An Empirical Study.” Supply Chain Management: An International Journal 18 (6): 604-617. doi: http://dx.doi.org/10.1108/SCM-10-2012-0331.

Griffith, R., E. Huergo, J. Mairesse, and B. Peters. 2006. "Innovation and Productivity across Four European Countries." Oxford Review of Economic Policy 22 (4): 483498. doi: https://doi.org/10.1093/oxrep/grj028.

Gunasekaran, A., C. Patel, and E. Tirtiroglu. 2001. "Performance Measures and Metrics in a Supply Chain Environment." International Journal of Operations \& Production $\quad$ Management $21 \quad$ (1/2): 71-87. doi: http://dx.doi.org/10.1108/01443570110358468.

Hair, J. F. Jr, W. C. Black, B. J. Babin, and R. E. Anderson. 2010. Multivariate Data Analysis: A Global Perspective, 7th ed., Upper Saddle River, NJ: Pearson Education. 
Halley, A., and M. Beaulieu. 2009. "Mastery of Operational Competencies in the Context of Supply Chain Management.” Supply Chain Management: An International Journal 14 (1): 49-63. doi: http://dx.doi.org/10.1108/13598540910927304.

Hallgren, M., and J. Olhager. 2009. "Flexibility Configurations: Empirical Analysis of Volume and Product Mix Flexibility." Omega 37 (4): 746-756. doi: http://doi.org/10.1016/j.omega.2008.07.004.

Hornibrook, S., A. Fearne, and M. Lazzarin. 2009, "Exploring the Association between Fairness and Organisational Outcomes in Supply Chain Relationships.” International Journal of Retail \& Distribution Management 37 (9): 790-803. doi: http://dx.doi.org/10.1108/09590550910975826.

Huang, M. C., G. F. Yen, and T. C., Liu. 2014. "Reexamining Supply Chain Integration and the Supplier's Performance Relationships under Uncertainty.” Supply Chain Management: An International Journal 19 (1): 64-78. doi: http://dx.doi.org/10.1108/SCM-04-2013-0114.

Hult, G. T., R. F. Hurley, and G. A. Knight. 2004. "Innovativeness: Its Antecedents and Impact on Business Performance.” Industrial Marketing Management 33 (5): 429-438. doi: http://doi.org/10.1016/j.indmarman.2003.08.015.

Jack, E., and A. Raturi. 2002. "Sources of Volume Flexibility and Their Impact on Performance.” Journal of Operations Management 20 (5): 519-548. doi: http://doi.org/10.1016/S0272-6963(01)00079-1.

Kang, K., and H. Park. 2012. "Influence of Government R\&D Support and Inter-Firm Collaborations on Innovation in Korean Biotechnology SMEs.” Technovation 32 (1): 68-78. doi: http://doi.org/10.1016/j.technovation.2011.08.004.

Kim, J., and P. Arnold. 1993. "Manufacturing Competence and Business Performance: A Framework and Empirical Analysis." International Journal of Operations \& 
Production $\quad$ Management $13 \quad$ (10): 4-25. doi: http://dx.doi.org/10.1108/01443579310045518.

Kimura, F., Y. Matoba, and K. Mitsui. 2007. "Designing Product Reliability Based on Total Product Lifecycle Modelling.” CIRP Annals - Manufacturing Technology 56 (1): 163-166. doi: https://doi.org/10.1016/j.cirp.2007.05.039.

Kleinschmidt, E. J., and R. G. Cooper. 1991. "The Impact of Product Innovativeness on Performance.” Journal of Product Innovation Management 8 (4): 240-251. doi: https://doi.org/10.1016/0737-6782(91)90046-2.

Laosirihongthong, T., D. Prajogo, and D. Adebanjo. 2014. “The Relationships between Firm's Strategy, Resources, and Innovation Performance: Resources-Based View Perspective." Production Planning and Control 25 (15): 1231-1246. doi: http://dx.doi.org/10.1080/09537287.2013.819593.

Laosirihongthong, T., P. Punnakitikashem, and D. Adebanjo. (2013) “Improving Supply Chain Operations By Adopting RFID Technology: Evaluation and Comparison of Enabling Factors." Production Planning and Control 24 (1): 90-109. doi: http://dx.doi.org/10.1080/09537287.2011.600807.

Lee, C. W., I. W. Kwon, and D. Severance. 2007. "Relationship between Supply Chain Performance and Degree of Linkage among Supplier, Internal Integration, and Customer." Supply Chain Management: An International Journal 12 (6): 444452. doi: http://dx.doi.org/10.1108/13598540710826371.

Leskovar-Spacapan, G., and M. Bastic. 2007. “Differences in Organizations’ Innovation Capability in Transition Economy: Internal Aspect of the Organizations' Strategic Orientation." Technovation $27 \quad$ (9): 533-546. doi: http://doi.org/10.1016/j.technovation.2007.05.012. 
Lin, B. 2004. "Original Equipment Manufacturers (OEM) Manufacturing Strategy for Network Innovation Agility: The Case of Taiwanese Manufacturing Networks." International Journal of Production Research 42 (5): 943-957. doi: http://dx.doi.org/10.1080/00207540310001622449.

Linton, J. 2015. "Teaching Innovation to Technologists (Non-Business People) and NonTechnologists (Business People): Scotch Whisky as an Exemplar of Process Changing Product an Alternative to Traditional Lectures." Technological Forecasting and Social Change 100: 39-43. doi: http://doi.org/10.1016/j.techfore.2015.05.001.

Lu, Q., and B. Botha. 2006. "Process Development: A Theoretical Framework." International Journal of Production Research 44 (15): 2977-2996. doi: http://dx.doi.org/10.1080/00207540600547430.

Mackelprang, A., M. Habermann, and M. Swink. 2015. "How Firm Innovativeness and Unexpected Product Reliability Failures Affect Profitability.” Journal of Operations $\quad$ Management $\quad 38:$ 71-86. doi: http://doi.org/10.1016/j.jom.2015.06.001.

Martínez-Ros, E., and J. M. Labeaga. 2009. "Product and Process Innovation: Persistence and Complementarities." European Management Review 6 (1): 64-75. doi: 10.1057/emr.2009.4.

Mendes, L., and J. Machado. 2015. “Employees' Skills, Manufacturing Flexibility and Performance: A Structural Equation Modelling Applied to the Automotive Industry.” International Journal of Production Research 53 (13): 4087-4101. doi: http://dx.doi.org/10.1080/00207543.2014.993772. 
Meyer, J., and B. Rowan. 1977. "Institutionalized Organizations: Formal Structure as Myth and Ceremony." American Journal of Sociology 83 (2): 340-363. doi: $10.1086 / 226550$.

Mishra, A., A. Chandrasekaran, and A. MacCormack. 2015. "Collaboration in MultiPartner R\&D Projects: The Impact of Partnering Scale and Scope.” Journal of Operations $\quad$ Management 33-34: 1-14. doi: http://doi.org/10.1016/j.jom.2014.09.008.

Morton, S. and N. Burns. 2008. "Understanding and Overcoming Resistance to Innovation." In Creating Wealth from Knowledge: Meeting the Innovation Challenge, edited by John Bessant and Tim Venables, 251-272. Cheltenham, UK: Edward Elgar.

Moyano-Fuentes, J., M. Sacristán-Díaz, and P. Garrido-Vega. 2016. “Improving Supply Chain Responsiveness through Advanced Manufacturing Technology: The Mediating Role of Internal and External Integration." Production Planning \& Control 27 (9): 686-697. doi: http://dx.doi.org/10.1080/09537287.2016.1166277.

Näslund, D., and H. Hulthen. 2012. "Supply Chain Management Integration: A Critical Analysis." Benchmarking: An International Journal 19 (4/5): 481-501. doi: http://dx.doi.org/10.1108/14635771211257963.

Oke, A., and A. Kach. 2012, "Linking Sourcing and Collaborative Strategies to Financial Performance: The Role of Operational Innovation.” Journal of Purchasing and Supply Management $18 \quad$ (1): 46-59. doi: http://doi.org/10.1016/j.pursup.2012.01.001.

Paashuis, V., and H. Boer. 1997. "Organizing for Concurrent Engineering: An Integration Mechanism Framework.” Integrated Manufacturing Systems 8 (2): 79-89. doi: http://dx.doi.org/10.1108/09576069710165765. 
Peteraf, M. 1993. The Cornerstones of Competitive Advantage: A Resource-based View." Strategic Management Journal 14 (3): 179-191. doi: 10.1002/smj.4250140303.

Pietrobelli, C., and R. Rabellotti. 2011. “Global Value Chains Meet Innovation Systems: Are There Learning Opportunities for Developing Countries? World Development 39 (7): 1261-1269. doi: http://doi.org/10.1016/j.worlddev.2010.05.013.

Preacher, K. J., and A. F. Hayes. 2004. "SPSS and SAS procedures for estimating indirect effects in simple mediation models.” Behavior Research Methods, Instruments, \& Computers 36 (4): 717-731. doi:10.3758/BF03206553.

Rao, P., R. Chandra, and J. Shin. 2012. "R\&D Offshoring in Multinational Enterprises: Relevance of Transaction Cost and Internalization Theories.” Competitiveness Review: An International Business Journal 22 (5): 376-395. doi: http://dx.doi.org/10.1108/10595421211266276.

Ren, S., A. B., Eisingerich, and H. Tsai. 2015. "Search Scope and Innovation Performance of Emerging-Market Firms.” Journal of Business Research 68 (1): 102-108. doi: http://doi.org/10.1016/j.jbusres.2014.04.011.

Sarkis, J. (2012), “A boundaries and flows perspective of green supply chain management”, Supply Chain Management: An International Journal, Vol. 17 No. 2, pp. 202-216.

Scott, W. R. 1995. Institutions and Organizations: Ideas, Interests and Identities. Thousand Oaks, California: SAGE Publications.

Scott, W. R. 2008. Institutions and Organizations: Ideas and Interests. London: SAGE Publications.

Seo, Y., J. Dinwoodie, and D. Kwak. 2014. "The Impact of Innovativeness on Supply Chain Performance: Is Supply Chain Integration A Missing Link?” Supply Chain 
Management: An International Journal 19 (5/6): 733-746. doi: http://dx.doi.org/10.1108/SCM-02-2014-0058.

Shi, V. G., L. S. C., Koh, J. Baldwin, and F. Cucchiella. 2012. "Natural Resource Based Green Supply Chain Management.” Supply Chain Management: An International Journal 17 (1): 54-67. doi: 10.1108/13598541211212203.

Shum, P., and G. Lin. 2007. “A World Class New Product Development Best Practices Model." International Journal of Production Research 45 (7): 1609-1629. doi: http://dx.doi.org/10.1080/00207540600942516.

Sitkin, S., K. M. Sutcliffe, and R. Schroeder. 1994. "Distinguishing Control from Learning in Total Quality Management: A Contingency Perspective.” Academy of Management Review 19 (3): 537-564. doi: 10.5465/AMR.1994.9412271813.

Søndergaard, E., J. Oehmen, and S. Ahmed-Kristensen. 2016. "Extension of Internationalisation Models: Drivers and Processes for the Globalisation of Product Development - A Comparison of Danish and Chinese Engineering Firms." Production Planning \& Control 27 (13): 1112-1123. doi: http://dx.doi.org/10.1080/09537287.2016.1186849.

Souitaris, V. 2001. "External Communication Determinants of Innovation in the Context of a Newly Industrialised Country: A Comparison of Objective and Perceptual Results from Greece." Technovation 21 (1): 25-34. doi: http://doi.org/10.1016/S0166-4972(00)00014-6.

Spekman, R. E. 1988. “Strategic Supplier Selection: Understanding Long-Term Buyer Relationships.” Business Horizons 31 (4): 75-81. doi: https://doi.org/10.1016/0007-6813(88)90072-9.

Stanger, S. H., R. Wilding, E, Hartmann, N. Yates, and S. Cotton. 2013. "Lateral Transshipments: An Institutional Theory Perspective." International Journal of 
Physical Distribution \& Logistics Management 43 (9): 747-767. doi: http://dx.doi.org/10.1108/IJPDLM-09-2011-0155.

Tavassoli, S., and C. Karlsson. 2015. "Persistence of Various Types of Innovation Analyzed and Explained." Research Policy 44 (10): 1887-1901. doi: http://doi.org/10.1016/j.respol.2015.06.001.

Teece, D. J. 2010. "Business Models, Business Strategy and Innovation.” Long Range Planning 43 (2-3): 172-194. doi: http://doi.org/10.1016/j.lrp.2009.07.003.

Tsai, J. M., and S. W. Hung. 2016. "Supply Chain Relationship Quality and Performance in Technological Turbulence: An Artificial Neural Network Approach." International Journal of Production Research 54 (9): 2757-2770. doi: http://dx.doi.org/10.1080/00207543.2016.1140919.

Wagner, H., S. C. Morton, A. R. Dainty, and N. Burns. 2011. "Path Dependent Constraints on Innovation Programmes in Production and Operations Management.” International Journal of Production Research 49 (11): 3069-3085. doi: http://dx.doi.org/10.1080/00207543.2010.482569.

Wiengarten, F., M. Pagell, M. U. Ahmed, and C. Gimenez. 2014. "Do A Country's Logistical Capabilities Moderate the External Integration Performance Relationship?" Journal of Operations Management 32 (1-2): 51-63. doi: http://doi.org/10.1016/j.jom.2013.07.001.

Winter, S., and R. Lasch. 2016. "Recommendations for Supplier Innovation Evaluation from Literature and Practice.” International Journal of Operations \& Production Management 36 (6): 643-664. doi: 10.1108/IJOPM-07-2014-0341.

Xu, Q., and R. Chi. 2009. "Comparing R\&D Consortia in Taiwan and the Chinese Mainland." European Business Review 21 (5): 481-497. doi: http://dx.doi.org/10.1108/09555340910986691. 
Yang, J., K. H. Lai, J. Wang, R. Rauniar, H. Xie. 2015. “Strategic Alliance Formation and the Effects on the Performance of Manufacturing Enterprises from Supply Chain Perspective.” International Journal of Production Research 53 (13): 38563870. doi: http://dx.doi.org/10.1080/00207543.2014.974843

Yeung, A. C. L., T. C. E. Cheng, and K. H. Lai. 2006. “An Operational and Institutional Perspective on Total Quality Management." Production and Operations Management 15 (1): 156-170.

Yeung, A. C. L., K. H. Lai, and R. W. Yee. 2007. "Organizational Learning, Innovativeness, and Organizational Performance: A Qualitative Investigation.” International Journal of Production Research 45 (11): 2459-2477. doi: http://dx.doi.org/10.1080/00207540601020460.

Zhu, Q., and J. Sarkis. 2004. "Relationships between Operational Practices and Performance among Early Adopters of Green Supply Chain Management Practices in Chinese Manufacturing Enterprises." Journal of Operations Management 22 (3): 265-289. doi: http://doi.org/10.1016/j.jom.2004.01.005.

Zhu, Q., and J. Sarkis. 2007. "The Moderating Effects of Institutional Pressures on Emergent Green Supply Chain Practices and Performance.” International Journal of Production Research 45 (18-19): 4333-4355. doi: http://dx.doi.org/10.1080/00207540701440345.

\section{Acknowledgements}

A special thanks and acknowledgement goes to the project partners of the sixth edition of International Manufacturing Strategy Survey (IMSS) in the data collection. 